\title{
WHO IS GOD
}

\section{STEPHEN R. L. CLARK}

University of Liverpool

\begin{abstract}
The Hindu Brahmanas record that God's reply to the question 'Who are you?' was simply 'Who': 'Who is the God whom we should honour with the oblation': an indicative, as well as interrogative! Might this also be what Aeschylus intended by his reference to 'Zeus hostis pot'estin' (Zeus, whoever He is): not an expression of doubt, but of acknowledged mystery? The name by which He is to be called, perhaps ('if it pleases Him'), is not 'Zeus' but, exactly, 'Whoever'. And most famously the God that Moses encountered, asked who He is, answered only 'I am'. What does this apparently evasive response imply for worship and theology in the light of David Hume's enquiry, how an unknowable God differs from an equally unknowable non-God? Rather than asking what God is we can investigate instead what worship is, perceiving our response to the Unknown as itself a revelation. In Orthodox terms, what we can share with God is not His Essence, but His Energeiai: not what He Is, but what He does.
\end{abstract}

\section{WHAT IS UNKNOWN FOREVER}

The Hindu Brahmanas record that God's reply to the question 'Who are you?' was simply 'Who': 'Who is the God whom we should honour with the oblation': an indicative, as well as interrogative! Might this also be what Aeschylus intended by his reference to 'Zeus hostis potestin' (Zeus, whoever He is): not an expression of doubt, but of acknowledged mystery? The name by which He is to be called, perhaps ('if it pleases Him'), is not 'Zeus' but, exactly, 'Whoever.'. And most famously the God that Moses encountered, asked who He is, answered only 'I am.'

${ }^{1}$ Wendy Doniger, The Hindus: An Alternative History (Oxford: Oxford University Press, 2009), p. 136, after Aitareya Brahmana 3.21, Rig Veda 1.121.

2 Aeschylus, Agamemnon, 160; see Leon Goldin, 'Zeus, Whoever He is ..., Transactions and Proceedings of the American Philological Association, 92 (1961), pp. 156-167.

${ }^{3}$ Exodus 3.14. 
Even in modern times, and without the author's own endorsement, the theme persists: when Frodo asks Goldberry, Tom Bombadil's partner and beloved, who Tom is, she answers 'He is'. Tolkien himself, of course, flatly denied - as a good Catholic - his readers' thought that Tom was intended at least to represent Eru, the One: oldest and fatherless, unfazed by the lure or threat of power, instantly available to offer help against oppression, but confined, by his own will, within the boundaries he has set, so as to allow others their simple chance of freedom. It is claimed, at the Council of Elrond, that Bombadil has less power than Sauron. But Tolkien himself would have admitted that authors are not the only or even the best interpreters, and even the Wise make mistakes ${ }^{4}$ ! Whether this is a good reading, one might say, who knows! Which is to say, God knows.

Another intriguing literary reference - to which I shall return - is in Kipling's Kim. Kim himself, in the aftermath of fever and excitement, is driven to ask of himself again and again, 'what is Kim?.' Wendy Doniger has observed that 'kim' in Sanskrit means 'what?', so that Kim's question amounts to 'What is What': 'a statement rather than a question'.

But I shall be taking my cue from ancient sources rather than more modern ones, and seeking rather to unravel what was meant in the anecdote David Hume quoted:

According to the famous story, Hiero asked [Simonides] 'What is God?', and [he] asked for a day to think about it, and then two days more; and in that way he continually prolonged his time for thinking about it, without ever producing a definition or description. Could you even blame me if I answered straight off that I didn't know what God is, and was aware that this subject lies vastly beyond the reach of my faculties? You might cry 'Sceptic!' and 'Tease!' as much as you pleased; but having found the imperfections and even contradictions of human reason when it is exercised on so many other subjects that are much more familiar

${ }^{4}$ See The Letters of J. R. R. Tolkien, ed. by Humphrey Carpenter (Boston: Houghton Mifflin, 1981), $\$ 144, \$ 153$; also Letters $\$ 19$, where (some years before the character was incorporated into The Lord of the Rings) he describes Bombadil as 'the spirit of the (vanishing) Oxford and Berkshire countryside'; Steuard Jensen 'What is Tom Bombadil': http://tolkien.slimy.com/essays/Bombadil.html (accessed 5 January 2017) firmly rejects even the hypothesis that Bombadil is a god (one of the Valar, in Tolkien's mythology), let alone Eru, the One.

${ }^{5}$ Rudyard Kipling Kim (New York: Doubleday, 1901), p. 367.

${ }^{6}$ Doniger, op.cit., p. 607. 
than this one, I would never expect any success from reason's feeble conjectures concerning a subject that is so elevated and so remote from the sphere of our observation. ${ }^{\text {? }}$

The God - distinct from any lesser, simpler, easily described divinities that emerges into human consciousness in India, Greece or Palestine is a question-mark, an unanswered and unanswerable question. Even theologians who are usually taken to be fairly robust and literal-minded in their interpretation of scripture share the notion. This is why ' $\mathrm{He}$ spreads out Time so long and Heaven so deep ... lest if we never met the dark, and the road that leads nowhither, and the question to which no answer is imaginable, we should have in our minds no likeness of the Abyss of the Father, into which if a creature drop down his thoughts for ever he shall hear no echo return to him.'

Many commentators, perhaps the majority, have glossed the declaration simply to say either that we can have no idea what the origin and explanation of reality may be, or else - a little more constructively that God is essential being: that which is, without any need for further cause or explanation, 'Oldest and Fatherless'. That cause and origin of all things else must certainly be, but what exactly It is in itself, lies outside our comprehension, precisely because to 'comprehend' anything is to see how it arises from a larger or deeper truth. This is not, in itself, particularly strange. Aphoristically, we may know that something is long before we know what it is (that is, what explanation there is for its existence or its character). ' 'Dark Matter', after all, has been hypothesised by physicists to explain why galaxies hang together as they rotate, just as the planet Neptune was hypothesised to explain discrepancies between the observed movement of the visible planetary bodies and those predicted in an otherwise successful gravitational theory. Neptune whatever it might be - was spotted once the astronomers knew where to look. Similarly, Mendelian inheritance was accepted as a fact long before we had any idea how it worked, or what 'genes', as units of inheritance, might be. 'Dark Matter' may eventually be identified by something more than its effects, but till then we may reasonably say that we can be

\footnotetext{
7 David Hume, Dialogues Concerning Natural Religion [1779], and The Natural History of Religion [1777], ed. by J. C. A. Gaskin (New York: Oxford University Press, 1993), p. 51 (Philo speaks), after Cicero, De Natura Deorum, 1.22.

${ }^{8}$ C. S. Lewis, Perelandra (New York: Macmillan, 1965 [1944]), p. 218.

${ }^{9}$ Aristotle, Posterior Analytics, B.1, 89b24ff.
} 
confident that it exists without any idea of what it is - except that there is, apparently, much more of it than of any visible matter. 'Dark Energy' is yet more opaque - an influence that causes the cosmos to be expanding faster than is otherwise expected, but which features in our theories only as a fudge factor to allow us to retain the basic structure of current cosmology. Either we shall eventually discover what the 'darkness' holds and recognize it as - somehow - of a piece with visible matter and familiar forces, or else we may decide that these seeming entities are only 'imaginary' mathematicals, like the square root of minus-one, ways of making our theories manageable but having no distinct, 'real', referent - very much as Cardinal Bellarmine (April 1615) chose to treat the Copernican hypothesis.

That God is what we do not and cannot know, the utterly unknowable, is itself an answer to one common form of argument occasionally heard even at the conference where this paper was first presented: what would be true if I were God? Richard Owen - the eminent palaeontologist who gave us Dinosaurs - argued that there must be intelligent life on Jupiter (and other similar planets) since there would otherwise be no-one to admire the spectacle of the Jovian moons. William Whewell - who gave us Scientists - acidly responded that we did not know God's plans for other worlds. ${ }^{10}$ Atheistical theologians commonly conclude the converse: if things aren't as they imagine 'God' should have them be, then God - so imagined - cannot exist. To which George Berkeley's comment (via his character Crito) seems an apt response: 'he who undertakes to measure without knowing either [the measure or the thing to be measured] can be no more exact than he is modest, ... who having neither an abstract idea of moral fitness nor an adequate idea of the divine economy shall yet pretend to measure the one by the other.' ${ }^{11}$ And more generally: 'I do not therefore conclude a thing to be absolutely invisible, because it is so to me. ... [and] dare not pronounce a thing to be nonsense because I do not understand it.' ${ }^{12}$ So also Isaac Newton:

Without all doubt this world could arise from nothing but the perfectly free will of God. ... From this fountain ... [what] we call the laws of

${ }^{10}$ William Whewell, Of the Plurality of Worlds, ed. by Michael Ruse (Chicago: University of Chicago Press, 2001); 1st published as Of the Plurality of Worlds: An Essay (London: John W. Parker, 1853), pp. 183-4.

${ }^{11}$ Alciphron (Crito speaks): George Berkeley, Works, A. A. Luce \& T. E. Jessop (eds), Vol. 3 (Edinburgh: Thomas Nelson, 1950 [1732]), pp. 251-2.

12 Alciphron (Euphranor speaks): Works, vol.3, p. 229. 
nature have flowed, in which there appear many traces indeed of wise contrivance, but not the least shadow of necessity. These therefore we must not seek from uncertain conjectures, but learn them from observations and experiments. He who is presumptuous enough to think that he can find the true principles of physics and the laws of natural things by the force alone of his own mind, and the internal light of reason, must either suppose that the world exists by necessity, and by the same necessity follows the laws proposed; or if the order of Nature was established by the will of God, that himself, a miserable reptile, can tell what was fittest to be done. ${ }^{13}$

'My thoughts are not your thoughts, neither are your ways my ways, saith the Lord.'14

The unknown, invisible, incomprehensible God is not simply an Hebraic notion. Plotinus, speaking for most Platonists, insisted that an honest inquirer 'will learn that it is by means of the intelligible, but what it is like by letting the intelligible go.' ${ }^{15}$ And this too is in line with a more ancient Hellenic judgment. 'The lord whose oracle is in Delphi [which is to say, Apollo] neither speaks nor suppresses, but indicates. ${ }^{16}$

\section{THE HUMEAN RESPONSE}

But if we cannot say what God is, what is it that we are gesturing towards? What is being indicated? If we cannot conclude anything about what God would do or has done, what sort of explanation of reality is being offered? All we are left with is simply that things happen: 'the laws of nature' - even supposing we could discover them - are just descriptive. It is, as Wittgenstein remarked, a common modern illusion that 'the laws of nature' actually explain. ${ }^{17}$ Any hypothesis that has just anything as its effect is rather the rejection of all rational enquiry than its support.

${ }^{13}$ Isaac Newton as represented by Hooykaas, after Cotes' preface to second edition of Principia: R. Hooykaas, Religion and the Rise of Modern Science (Edinburgh: Scottish Academic Press, 1972), p. 49.

${ }^{14}$ Isaiah 55.8: chiefly, in the immediate context, that He pardons the repentant, but the saying has a larger range.

15 Plotinus, Ennead V.5 [32].6, 21-2.

${ }^{16}$ Heracleitos 22B93DK: Robin Waterfield, The First Philosophers: The PreSocratics and Sophists (Oxford: Oxford University Press, 2000), p. 40; see Peter Kingsley, In the Dark Places of Wisdom (Salisbury: Golden Sufi Center, 1999), p. 87: 'the oracles he gave out were full of riddles, full of ambiguities and traps.'

17 'At the basis of the whole modern view of the world lies the illusion that the socalled laws of nature are the explanations of natural phenomena' (L. von Wittgenstein, 
Which is of course exactly what Whewell said about the Darwinian hypothesis as he first understood it: the idea, for example, that there were once plant-forms fitted to years of different lengths (and only the ones that chanced to match the actual length of the terrestrial year survived) struck him as 'too gratuitous and extravagant to require much consideration. ${ }^{18}$ Bees did not explore every possible geometrical arrangement of their honeycombs before settling on producing hexagonal cells, any more than there were ever snowflakes built on a different template than the familiar six-pointed star. Darwinians can accommodate the criticism. Whewell would have an easier target in more modern attempts at 'explaining' this world here by supposing that all possible worlds exist somewhere or at some time. If all possible worlds exist then we have no reason to be surprised by any outcome, or even any sudden shift - as we might at first consider it - in what is happening. As I have pointed out many times before, even our notion of what counts as a resemblance, or what will count as 'doing the same thing', has no basis in any merely logical understanding. Robert Chambers, writing in Vestiges of the Natural History of the Creation, employed Charles Babbage's argument in his Ninth Bridgewater Treatise ${ }^{19}$ to say what was happening in the many biological transformations recorded in the rocks. The 'very same computer program' (as we would now call it) may conscientiously progress from 1 to 2 to 3 to every number up to $100,000,001$. The obvious inference is that it will continue 'in like fashion' - yet the numbers that followed in Babbage's simple computer were instead 100,010,002; $100,030,003 ; 100,060,004 ; 100,100,005 ; 100,150,006$ 'and so on' until the 2672nd term. A less imaginative scientist might have concluded only that the program was 'defective': Babbage recognized that the defect had only been in our perception. We cannot know till afterwards what was really happening earlier, and so have no way of telling, before the event, when chickens will start laying dinosaur eggs again!

So is there some way of avoiding the collapse of reason, while still

Tractatus Logic-Philosophicus, D. F. Pears \& B. F. McGuinness (eds) (London: Routledge \& Kegan Paul, 1972, 2nd ed.), 6.371).

${ }^{18}$ William Whewell's Bridgewater Treatise: Astronomy and General Physics considered with reference to Natural Theology (London: William Pickering, 1833, 2nd ed.), cited by David Hull The Metaphysics of Evolution (New York: SUNY Press, 1989), p. 33.

${ }^{19}$ Robert Chambers, Vestiges of the Natural History of Creation (Leicester: Leicester University Press; New York: Humanities Press, 1969 [1844]), after Charles Babbage, Ninth Bridgewater Treatise Fragment (London: Frank Cass, 1967 [1837]), pp. 34ff. 
remembering that the ultimate cause and context of reality is always beyond our grasp? Christian theologians - for example, Benedict XVI have insisted that human reason is indeed a model for the universe, if not for God. 'The objective structure of the universe and the intellectual structure of the human being coincide; the subjective reason and the objectified reason in nature are identical. In the end it is "one" reason that links both and invites us to look to a unique creative Intelligence. ${ }^{20}$ When Hume allowed his Pyrrho to enquire 'what peculiar privilege has this little agitation of the brain which we call thought, that we must thus make it the model of the whole universe?'21 it was with a view to mocking the idea that God might be like us - but that was always a heresy. The real problem with Hume's question is that it leaves us with no reason to think that any 'rational model' we might devise has any resemblance to the cosmic order. Why should we suppose that members of a particular hominid species, evolved by Darwinian processes, have any talents beyond those needed to survive and breed in particular terrestrial contexts? 'Darwin's theory makes the testable prediction that whenever we use technology to glimpse reality beyond the human scale, our evolved intuition should break down. ${ }^{22}$ Only if we have been made to mirror the cosmic order do we have any chance of doing so.

Far from undermining the credibility of theism, the remarkable success of science in modern times is a remarkable confirmation of the truth of theism. It was from the perspective of Judeo-Christian theism - and from that perspective alone - that it was predictable that science would have succeeded as it has. Without the faith in the rational intelligibility of the world and the divine vocation of human beings to master it, modern science would never have been possible, and, even today, the continued rationality of the enterprise of science depends on convictions that can be reasonably grounded only in theistic metaphysics. ${ }^{23}$

${ }^{20}$ Benedict XVI to Archbishop Rino Fisichella, on the occasion of the international congress 'From Galileo's Telescope to Evolutionary Cosmology' (30 November - 2 December 2009), available at: <http://www.vatican.va/holy_father/benedict_xvi/ messages/pont-messages/2009/documents/hf_ben-xvi_mes_20091126_fisichellatelescopio_en.html> [accessed 5 January 2017].

${ }^{21}$ David Hume, Dialogues Concerning Natural Religion, A. W. Colver \& J. V. Price (eds) (Oxford: Clarendon Press, 1976 [1777]), p. 168.

22 Max Tegmark, Our Mathematical Universe: My Quest for the Ultimate Nature of Reality (London: Allen Lane, 2014), p. 5.

${ }^{23}$ Robert C. Koons, 'Science and Theism: Concord not Conflict', in Paul Copan \& Paul Moser (eds), The Rationality of Theism (London: Taylor \& Francis, 2003), p. 82. The point 
But the problem still remains: what is the connection between the Unknown One, and the - possibly - knowable Cosmos? If we cannot tell what the Unknown would do, how can we expect that It would endow us with 'reason' or make the universe intelligible to us? How do 'mystics, who maintain the absolute incomprehensibility of the Deity, differ from Sceptics or Atheists, who assert, that the first cause of all is unknown and unintelligible?'24 We speak of 'Acts of God' or 'Miracles' to indicate what cannot reasonably be anticipated or contained within a universal law accessible to us. How then does 'God did it' differ from 'it happened, and no-one can know why'? How does Plotinus's One, veiled from us by the many forms of beauty, ${ }^{25}$ differ from his Matter, equally hidden behind 'golden chains'? ${ }^{26}$ Perhaps the difference - or at least a difference - lies in our response. The 'sceptic or atheist' is content to reckon that she has no explanation beyond the banal - non-explanatory - appeal to 'what usually happens. The 'mystic', while agreeing that the question 'why?' has no discernible answer, is still surprised by wonder, by the conviction that, somehow, the world is oriented toward some good, some attractor.

The man of science says "Cut the stalk, and the apple will fall", but he says it calmly as if the one idea really led up to the other. The witch in the fairy tale says, "Blow the horn and the ogre's castle will fall"; but she does not say it as if it were something in which the effect obviously arose out of the cause. ... The scientific men ... feel that because one incomprehensible thing constantly follows another incomprehensible thing the two together somehow make up a comprehensible thing. ... A tree grows fruit

was also made by Henry More: 'It is possible that Mathematical evidence it self, may be but a constant undiscoverable delusion, which our nature is necessarily and perpetually obnoxious to, and that either fatally or fortuitously there has been in the world time out of mind such a Being as we call Man, whose essential property is to be then most of all mistaken, when he conceives a thing most evidently true. And why may not this be as well as anything else, if you will have all things fatall or casuall without a God? For there can be no curbe to this wild conceipt, but by the supposing that we our selves exist from some higher Principle that is absolutely good and wise, which is all one as to acknowledge that there is a God' (An Antidote against Atheism (1653), Bk.1, ch.2: C. A. Patrides (ed.), The Cambridge Platonists (Cambridge University Press: Cambridge 1969), p. 214.

${ }^{24}$ David Hume, Dialogues Concerning Natural Religion [1779], and The Natural History of Religion [1777], ed. by J. C. A. Gaskin (New York: Oxford University Press, 1993), p. 60 (Cleanthes speaks).

${ }^{25}$ Ennead I.6 [1].9

${ }^{26}$ Ennead I.8 [51].15 
because it is a magic tree. Water runs downhill because it is bewitched. The sun shines because it is bewitched. ${ }^{27}$

In the nature of the case we cannot literally point to God, any more than we can 'reason' our way to an understanding of God's nature: that would require God to be in one place and not another, over there, not here. We can - though even this raises questions - point to devotees: if we cannot say what God is, can we at least say what worship is? 'To know God, says Seneca, is to worship him. All other worship - that is, all worship that goes beyond expressing one's knowledge that God exists - is indeed absurd, superstitious, and even impious. ${ }^{28}$ But though it is common practice to translate Seneca's aphorism, 'primus est deorum cultus deos credere', as meaning simply that 'the first way to worship the gods is to believe in the gods', to believe 'that they exist', this makes little sense. The devils also believe that much - and tremble! ${ }^{29}$ My suggestion is rather that the first step in worship is to believe [them] gods - those presences, that is, that can neither injure anything nor themselves be injured. ${ }^{30} \mathrm{He}$ continued with further requirements: 'the next [step is] to acknowledge their majesty, to acknowledge their goodness without which there is no majesty. ${ }^{31}$ Also, to

${ }^{27}$ G. K. Chesterton, Orthodoxy (London: Fontana, 1961 [1908]), pp. 50f. Chesterton's philosophy of science is examined by Stanley Jaki, Chesterton: A Seer of Science (Urbana: University of Illinois Press, 1986). See further my 'Science, Chesterton and the Will of the Creator', in Martin Stone (ed.), Reason, Faith and History: Essays for Paul Helm (London: Ashgate, 2008), pp. 115-25.

${ }^{28}$ Hume, op.cit., p. 128, quoting Seneca, Moral Epistles, 95.50 ('primus est deorum cultus deos credere'). I am not sure - in passing - whether later Thomistic analysis of the different phrases is any help here, except to emphasise the difficulty. Aquinas, Summa theologiae II-II.2.2c distinguishes 'credere Deo', 'credere Deum' and 'credere in Deum': 'One of these (1) is the material object of faith, and in this way an act of faith is "to believe in a God" (credere Deum); because, as stated above (ST II-II.1.1) nothing is proposed to our belief, except in as much as it is referred to God. The other (2) is the formal aspect of the object, for it is the medium on account of which we assent to such and such a point of faith; and thus an act of faith is "to believe God" (credere Deo), since, as stated above (ST II-II.1.1) the formal object of faith is the First Truth, to Which man gives his adhesion, so as to assent to Its sake to whatever he believes. Thirdly, if the object of faith be considered (B) insofar as the intellect is moved by the will, an act of faith is "to believe in God" (credere in Deum). For the First Truth is referred to the will, through having the aspect of an end.' See Fergus Kerr, After Aquinas: Versions of Thomism (London: WileyBlackwell, 2002), p. 67.

${ }^{29}$ James 2.19 .

${ }^{30}$ Seneca, Moral Epistles 95.49.

31 'Deinde reddere illis maiestatem suam, reddere bonitatem, sine qua nulla maiestas est'. 
know that they are supreme commanders in the universe, controlling all things by their power and acting as guardians of the human race. ${ }^{32}$

Would you win over the gods? Then be a good man. Whoever imitates them, is worshipping them sufficiently. Then comes the second problem, how to deal with men. What is our purpose? What precepts do we offer? Should we bid them refrain from bloodshed? What a little thing it is not to harm one whom you ought to help! It is indeed worthy of great praise, when man treats man with kindness! Shall we advise stretching forth the hand to the shipwrecked sailor, or pointing out the way to the wanderer, or sharing a crust with the starving? Yes, if I can only tell you first everything which ought to be afforded or withheld; meantime, I can lay down for mankind a rule, in short compass, for our duties in human relationships: all that you behold, that which comprises both god and man, is one - we are the parts of one great body. Nature produced us related to one another, since she created us from the same source and to the same end. She engendered in us mutual affection, and made us prone to friendships. She established fairness and justice; according to her ruling, it is more wretched to commit than to suffer injury. Through her orders, let our hands be ready for all that needs to be helped. ${ }^{33}$

And if we can, may not that be what 'God' means for us? To worship God it is enough to live as God lives, with unlimited generosity. 'God' is not first postulated or invented as an explanatory hypothesis: rather a particular form of life is recognized as godly.

There have been many frantic and blasphemous beliefs in this old barbaric earth of ours; men have served their deities with obscene dances, with cannibalism, and the blood of infants. But no religion was quite so blasphemous as to pretend that it was scientifically investigating its god to see what he was made of. Bacchanals did not say, 'Let us discover whether there is a god of wine'. They enjoyed wine so much that they cried out

32 The standard edition qualifies this by adding that 'they are sometimes unmindful of the individual', but note that 'unmindful' is an unsupported emendation of the recorded text: see R. W. Sharples 'Threefold Providence: the history and background of a doctrine', Bulletin of the Institute of Classical Studies, Supplement 78, Vol. 46 (Jan. 2003), pp. 107-127 (p. 115). Seneca may actually have intended that the gods are mindful of the individuals. See further Matthew W. Dickie 'Exclusions from the Catechumenate: continuity or discontinuity with pagan cult', Numen: International Review for the History of Religions, 48 (2001), 417-443, arguing that pagans, like Christians, thought moral character of importance in the cult.

${ }^{33}$ Seneca, 95.50-2. 
naturally to the god of it. Christians did not say, 'A few experiments will show us whether there is a god of goodness'. They loved good so much that they knew that it was a god. Moreover, all the great religions always loved passionately and poetically the symbols and machinery by which they worked - the temple, the coloured robes, the altar, the symbolic flowers, or the sacrificial fire. It made these things beautiful: it laid itself open to the charge of idolatry. And into these great ritual religions there has descended, whatever the meaning of it, the thing of which Sophocles spoke, "The power of the gods, which is mighty and groweth not old." 34

We can share in the life of God, His Energeiai, without understanding God's essence - the distinction was drawn early in Christian thought ${ }^{35}$ and is central to later Orthodox theology - to which I shall return. Earlier philosophers might seem rather to equate God's energeiai with His essence: 'life and aion continuous and eternal belong to the god, for this is what the god is. ${ }^{36}$ In Aristotle's vocabulary, God is Theoria, and that in turn is something very distant from mere abstract philosophizing. ${ }^{37}$ Theoria is a pure enjoyment of eternally living beauty: 'enjoyment' rather than the misleading 'contemplation' simply as the latter term suggests

${ }^{34}$ G. K. Chesterton 'Skepticism and Spiritualism', Illustrated London News, April 14, 1906, available from http://www.cse.dmu.ac.uk/ mward/gkc/books/skeptic.html [accessed 5 January 2017]. My guess is that the Sophocles reference is to Oedipus 86371: 'I pray fate still finds me worthy, demonstrating piety and reverence in all I say and do - in everything our loftiest traditions consecrate, those laws engendered in the heavenly skies, whose only father is Olympus. They were not born from mortal men, nor will they sleep and be forgotten. In them lives an ageless mighty god' (trans. by Ian Johnston: https://records.viu.ca/ johnstoi/sophocles/oedipustheking.htm, accessed 5 January 2017).

${ }^{35}$ It even appears in Philo, De Fuga, 164-5 (glossing Exodus 33.23): 'it is sufficient for the wise man to know the consequences, and the things which are after God; but he who wishes to see the principal essence will be blinded by the exceeding brilliancy of his rays before he can see it': Collected Works, trans. by F. H. Colson, G. H. Whitaker, et al. (London: Loeb Classical Library, Heinemann, 1929), vol.2, p. 228.

${ }^{36}$ Aristotle, Metaphysics, 12.1072b13f; see also Boethius, Consolation of Philosophy, 5.6. For further thoughts see my 'Therapy and Theory Reconstructed', Philosophy as Therapy, Royal Institute of Philosophy Supplementary Volume 66, Clare Carlisle \& Jonardon Ganeri (eds) (Cambridge: Cambridge University Press, 2010), pp. 83-102.

${ }^{37}$ Ennead V.8 [31].5f: 'one must not then suppose that the gods and the "exceedingly blessed spectators" in the higher world contemplate propositions (axiomata), but all the Forms we speak about are beautiful images in that world, of the kind which someone imagined to exist in the soul of the wise man, images not painted but real. This is why the ancients said that the Ideas were realities and substances.' 
a distance between the observer and the observed. And it is that delight by which we need to be guided. This is not necessarily always to exclude some 'explanatory' element: the point is that we are first introduced to God, or to the lesser gods, when our attention is fixed upon some special way of living. We may advance from that to insist that the God we have encountered, the form of life we have admired, is indeed the only Lord and Creator (in some fashion): we do not begin from an arbitrarily postulated Somewhat whose character or commands we only learn much later. ${ }^{38}$

But there is still good reason to distinguish the merely Aristotelian and the Orthodox: ${ }^{39}$ the former may easily give the impression that our questions will be answered, that we will or could 'know God'. 'Philosophy begins in wonder, ${ }^{40}$ and we are all likely to interpret 'wonder', here, as puzzlement, and so expect that we may one day unravel all the puzzles, from Dark Matter to Divinity, and be able to provide a single coherent account of all that is. We shall see - as Stephen Hawking hopes - that everything is as it is 'bound to be' (and everything is also bound to be). ${ }^{41}$ And on that day the 'wonder' will be no more. ${ }^{42}$ But 'wonder' has another

${ }^{38}$ See Alvin Plantinga, 'Darwin, Mind and Meaning' (1996), on the oddity of supposing that Moses, faced by the Burning Bush, arbitrarily postulated an otherwise unknown Creator of infinite power to 'explain' this! See http://maverickphilosopher. typepad.com/maverick_philosopher/2011/12/articles-by-alvin-plantinga.html (accessed 5 January 2017).

${ }^{39}$ David Bradshaw, Aristotle East and West: Metaphysics and the Division of Christendom (Cambridge University Press: Cambridge, 2004); see also Constantinos Athanasopoulos \& Christoph Schneider (eds), Divine Essence and Divine Energies: Ecumenical Reflections on the Presence of God in Eastern Orthodoxy (Cambridge: James Clarke \& Co., 2013). I reviewed the latter collection in Philosophical Quarterly, 64 (2014), 513-517.

${ }^{40}$ Aristotle, Metaphysics, 1.982b12, after Plato, Theaetetus 155d

41 'Even if there is only one possible unified theory, it is just a set of rules and equations. What is it that breathes fire into the equations and makes a universe for them to describe?' (Stephen Hawking, Brief History of Time (London: Bantam, 1988), p. 174). The later Hawking seems to have concluded that the 'laws' themselves can somehow compel the existence of the stuff whose motion they describe: see Stephen Hawking \& Leonard Mlodinow, The Grand Design (London: Bantam Press, 2010).

${ }^{42}$ Richard Dawkins, as so often, misses the point in saying that 'mysteries do not lose their poetry when solved', and that 'the solution often turns out more beautiful than the puzzle': Richard Dawkins, Unweaving the Rainbow: Science, Delusion and the Appetite for Wonder (London: Penguin, 2006), p. 41. The 'wonder' he would feel once the first puzzlement had abated, and its correspondent beauty, would, on his terms, be no more than an odd hormonal reaction selected by Darwinian evolution as - somehow - more 
meaning: it is how we feel (or should feel) in the face of unbounded mystery. 'You shall make no images of anything, to worship them, ${ }^{43}$ and the only answer to the question 'Who is God?' is Who - or in another style, 'Not this, not that': 'neti neti. ${ }^{44}$ Hume's Demea was partly accurate:

The ancient Platonists, you know, were the most religious and devout of all the pagan philosophers; yet many of them, particularly Plotinus, expressly declare that intellect or understanding is not to be ascribed to God, and that our most perfect worship of him consists not in acts of veneration, reverence, gratitude, or love but rather in a certain mysterious self-annihilation, or total extinction of all our faculties. ${ }^{45}$

Partly accurate, only: Plotinus was not rejecting intellect, but pointing towards its fulfilment.

Intellect ... has one power for thinking, by which it looks at the things in itself, and one by which it looks at what transcends it by a direct awareness and reception, by which also before it saw only, and by seeing acquired intellect and is one. And that first one is the contemplation of Intellect in its right mind, and the other is Intellect in love, when it goes out of its mind 'drunk with the nectar'; then it falls in love, simplified

prolific than its sometime rivals. As Robert Browning's Blougram asked, 'Does law so analysed coerce you much? Oh, men spin clouds of fuzz where matters end, But you who reach where the first thread begins, You'll soon cut that! - which means you can, but won't, Through certain instincts, blind, unreasoned-out, You dare not set aside, you can't tell why': Robert Browning, 'Bishop Blougram's Apology', Men and Women (1855), lines 834-9. Browning modelled Blougram on Cardinal Wiseman, and some Catholics found the portrait at least unflattering. I am not persuaded that they were right to do so. See F. E. L. Priestly 'Blougram's Apologetics', The University of Toronto Quarterly, 15 (1945-46), 139-47; Rupert E. Palmer, Jr 'The Uses of Character in "Bishop Blougram's Apology", Modern Philology, 58:2 (1960), 108-118, available at: http://www.jstor.org/stable/434633 [accessed 5 January 2017]; W. Wendell Howard 'Browning, Blougram and Belief', Logos: A Journal of Catholic Thought and Culture, 13.2 (2010), 79-93 (DOI: 10.1353/log.0.0074).

${ }^{43}$ Exodus 20.4-5; Deuteronomy 5.8-9.

${ }^{44}$ Brhadaranyaka Upanisad 2.3.6: 'The form of that "being" is as follows: Like a cloth dyed with turmeric, or like grey sheep's wool, or like the (scarlet) insect called Indragopa, or like a tongue of fire, or like a white lotus, or like a flash of lightning. He who knows it as such attains splendour like a flash of lightning. Now therefore the description (of Brahman): "Not this, not this". Because there is no other and more appropriate description than this "Not this". Now Its name: "The Truth of truth". The vital force is truth, and It is the Truth of that'. http://www.upanishads.kenjaques.org.uk/Brihadaranyaka_Upanishad_ Chapter_Two.html (accessed 5 January 2017). See Upanisads, trans. by Patrick Olivelle (New York: Oxford University Press, 1996), p. 28.

${ }^{45}$ Hume, op.cit., p. 58 (Demea speaks). 
into happiness (haplotheis eis eupatheian) by having its fill, and it is better for it to be drunk with a drunkenness like this than to be more respectably sober. ${ }^{46}$

Religion, like philosophy, begins in wonder: not so much 'Who?', perhaps, as 'Wow!'. This is true even if our response is 'polytheistic': there are many forms of beauty, many 'wonderful' moments. I shall not explore the ethical problems created when those forms seem to be at odds, or when - to a mature understanding - we rank them wrongly. In brief,

Moderns have neglected to subdue the gods of Priam. These gods are visions of the eternal attributes, or divine names, which, when erected into gods, become destructive of humanity. They ought to be the servants, and not the masters of man, or of society. They ought to be made to sacrifice to Man, and not man compelled to sacrifice to them; for when separated from man or humanity, who is Jesus the Saviour, the vine of eternity, they are thieves and rebels, they are destroyers. ${ }^{47}$

In more Plotinian mode, there is a difference between the heavenly and the fallen Aphrodite: only the former is loyal to the Father. ${ }^{48}$ In the end all the forms of beauty, all the great attractors, owe their grace to the light of the One: ${ }^{49}$ they are only steps, for us, on the way back home. There may even be humanly created works of art that help to lead us home.

Greatly daring was the wax that formed the image of the invisible Prince of the Angels, incorporeal in the essence of his form. But yet it is not without grace; for a man looking at the image directs his mind to a higher contemplation. No longer has he a confused veneration, but imprinting the image in himself he fears him as if he were present. The eyes stir up the depths of the spirit, and Art can convey by colours the prayers of the soul. ${ }^{50}$

${ }^{46}$ Plotinus, Ennead, VI.7 [38].35, 20-8. I have examined this metaphor at greater length in Plotinus: Myth, Metaphor and Philosophical Practice (Chicago: University of Chicago Press, 2016).

${ }^{47}$ William Blake 'A Descriptive Catalogue' (1809), Complete Writings, ed. by G. Keynes (London: Oxford University Press, 1966), p. 571.

${ }^{48}$ Ennead VI.9 [9].9, 28ff.

${ }^{49}$ See Ennead VI.7 [38].22, 27-32.

${ }^{50}$ Agathias (536-82), W. R. Paton, Greek Anthology (London: Loeb Classical Library, Heinemann, 1916), 1.34, quoted by Gervase Mathew, Byzantine Aesthetics (John Murray: London. 1973), p. 78. Further on icons as gateways to the 'other' world, see C. A. Tsakiridou, Icons in Time, Persons in Eternity (Furnham: Ashgate, 2013). 


\section{THE PERSONAL MYSTERY}

Where especially may we encounter mystery? The answer - already implicit in my quotation from William Blake - may serve also to indicate another way of conceiving the difference between Hume's 'mystic' and his 'sceptic': we are to ask or assert that 'Who is God', not 'What is God', even though it is often helpful to consider God as 'the Place', so as to avoid any suggestion that God is one being amongst many. 'Why is God called "the Place" (hamaqom)? Because the universe is located in Him, not He in the universe. ${ }^{51}$ The mystery is ubiquitous, but we can understand a little more about it by considering the personal encounter.

A person is a mystery, never totally circumscribed by a definition, that is, as an essence or a "what." A person is not a "what" but a "who," and "who" you are, just as Who God is, is ultimately indefinable, undetermined, and of infinite depth. To say "what" something is, is to circumscribe that something in terms of essence or essential definition; to say "who" is to speak, not of some "thing" which can be defined in terms of its essence, but of some "one," an ultimately uncircumscribable and indefinable "who." 52

The passage I quoted earlier from Tolkien's story comes close to the same point, though without any special emphasis: when Frodo asks Bombadil who he is, Bombadil replies 'Tell me, who are you, alone, yourself and nameless? ${ }^{53}$ No-one is to be summed up simply as a particular sort of creature, even an accidentally unique one. Josiah Royce even used this fact - that we would not be comforted for the loss of our beloved by the provision even of a humanly indistinguishable twin - to suggest that love requires immortality. ${ }^{54}$ Individual identity is not merely a psychological problem, but a 'metaphysical mystery'. 'The lover says that he loves but One. Yet when he tells about her he describes a type. ${ }^{55}$ Royce concluded, in apparent agreement with Plotinus, that we all exist as fully realized

${ }^{51}$ [Midrash] Genesis R.68: Hyam Maccoby, Philosophy of the Talmud (London: Routledge, 2002), p. 24.

52 Vincent Rossi, 'Presence, Participation, Performance: The Remembrance of God in the Early Hesychast Fathers', in James S. Cutsinger (ed.), Paths to the Heart: Sufism and the Christian East (Bloomington, IN: World Wisdom, 2004), pp. 64-111 (p. 79).

${ }_{53}$ J. R. R. Tolkien, Fellowship of the Ring, op.cit., p. 142.

${ }^{54}$ Josiah Royce, The Conception of Immortality (Cambridge, Mass: Riverside Press, 1900), p. 37.

${ }^{55}$ Royce, op.cit., p. 34. 
individuals in the 'realm of a reality that is not visible to human eyes. ${ }^{56}$ As Plotinus insisted, 'it is by the one that all beings are beings, ${ }^{57}$ and our present, material existence rather conceals our true identities. 'For here below, too, we can know many things by the look in people's eyes when they are silent; but There [that is, in the divine, in the world as it is properly perceived] all their body is clear and pure and each is like an eye, and nothing is hidden or feigned, but before one speaks to another that other has seen and understood. ${ }^{58}$ And it is in this recognition that we also discover God:

In every sphere, in every relational act, through everything that becomes present to us, we gaze toward the train of the eternal You; in each we perceive a breath of it, in every you we address the eternal You, in every sphere according to its manner. All spheres are included in it, while it is included in none. Through all of them shines the one presence. ${ }^{59}$

The usual assumption, for those who thus emphasise the mystery of personal being, is that it is only in human beings, people, that the mystery is encountered. 'We characterize God's mode of being as personal, primarily because it corresponds to the experience we have of human personal existence: existence with self-consciousness, with rational relatedness, with ecstatic (active) otherness and freedom from any predetermination. ${ }^{30}$ That is not entirely my own experience, though I accept Christos Yannaras' characterization of God's activity as one of 'personal relationship and loving communion'. Anything at all may suddenly be there for us, may wake us up, whether an octopus suddenly looking back at us or a tree suddenly more than a merely leafy plant. 'Each grain of sand, every stone on the land, each rock and each hill, each fountain and rill, each herb and each tree, Mountain, hill, earth, and sea, Cloud, meteor, and star, Are men seen afar' ${ }^{\prime} 1$ - not because Blake

\footnotetext{
${ }^{56}$ Royce, op.cit., p. 75.

${ }_{57}$ Plotinus, Ennead, VI.9 [9].1, 1.

${ }^{58}$ Plotinus, Ennead, IV.3 [27].18, 19-24.

${ }^{59}$ Martin Buber, I and Thou (New York: Simon \& Schuster, 1996 [1923]), trans. by Walter Kaufmann, p. 150.

${ }^{60}$ Christos Yannaras, On the Absence and Unknowability of God: Heidegger and the Areopagite, trans. by Andrew Louth (London: T \& T Clark, 2005 [1986]), p. 85.

${ }^{61}$ William Blake, 'Letter to Thomas Butts' (2 October 1800)': Keynes (ed.), Complete Writings of William Blake, op.cit., pp. 804-5. Kathleen Raine, Blake and the New Age (London: Routledge, 2011), pp. 116-8 identifies Swedenborg as the source of Blake's conception.
} 
imagined them to be our conspecifics, nor even that they were 'like' us, but because each such thing is more than its own form. Something like the same shock of reality is aptly described by Chesterton:

Possibly the most pathetic of all the delusions of the modern students of primitive belief is the notion they have about the thing they call anthropomorphism. They believe that primitive men attributed phenomena to a god in human form in order to explain them, because his mind in its sullen limitation could not reach any further than his own clownish existence. The thunder was called the voice of a man, the lightning the eyes of a man, because by this explanation they were made more reasonable and comfortable. The final cure for all this kind of philosophy is to walk down a lane at night. Anyone who does so will discover very quickly that men pictured something semi-human at the back of all things, not because such a thought was natural, but because it was supernatural; not because it made things more comprehensible, but because it made them a hundred times more incomprehensible and mysterious. For a man walking down a lane at night can see the conspicuous fact that as long as nature keeps to her own course, she has no power with us at all. As long as a tree is a tree, it is a top-heavy monster with a hundred arms, a thousand tongues, and only one leg. But so long as a tree is a tree, it does not frighten us at all. It begins to be something alien, to be something strange, only when it looks like ourselves. When a tree really looks like a man our knees knock under us. And when the whole universe looks like a man we fall on our faces. ${ }^{62}$

Its 'looking like ourselves' means mostly that it suddenly becomes real to us, and at the same time utterly alien and mysterious. As I indicated before, God is not an explanatory hypothesis, but the mystery itself of being. A 'personal' relationship, so to call it, does not require or even permit that we understand our beloveds, but that we come to share their life without ever, quite, being them. So also Martin Buber:

The tree is no impression, no play of my imagination, no aspect of a mood; it confronts me bodily and has to deal with me as I must deal with it - only differently. One should not try to dilute the meaning of the relation: relation is reciprocity. Does the tree then have consciousness, similar to our own? I have no experience of that. But thinking that you have brought this off in your own case, must you again divide the

${ }^{62}$ G. K. Chesterton, 'Science and the Savages', Heretics (London: Bodley Head, 1905), p. 63. 
indivisible? What I encounter is neither the soul of a tree nor a dryad, but the tree itself. ${ }^{63}$

\section{SUMMARY CONCLUSION}

I follow Orthodox tradition in declaring that God's essence must always lie beyond our comprehension but that we may come to share God's energeiai through worship: that is to say, through our acknowledgement of mystery, our being confronted by the reality of His presence.

The sacred is here and now. The only God worth keeping is a God that cannot be kept. The only God worth talking about is a God that cannot be talked about. God is no object of discourse, knowledge or even experience. He cannot be spoken of, but he can be spoken to; he cannot be seen, but he can be listened to. The only possible relationship with God is to address him and to be addressed by him, here and now - or, as Buber puts it, in the present. For him the Hebrew name of God, the tetragrammaton $(Y H V H)$, means HE IS PRESENT. Er ist da might be translated $\mathrm{He}$ is there; but in this context it would be more nearly right to say: $\mathrm{He}$ is here. ${ }^{64}$

In this I am, in a way, rejecting the assumption lurking in the theme of the present volume - that 'God is hidden'. By my account He is hidden only in that He is forever present - luminously so for anyone who can, for a while, stop talking, and be turned to face - as it were - the presence merely mirrored in our ordinary concerns.

When we look outside that on which we depend we do not know that we are one, like faces which are many on the outside but have one head inside. But if someone is able to turn around, either by himself or having the good luck to have his hair pulled by Athena herself, he will see God and himself and the all.... He will stop marking himself off from all being and will come to all the All without going out anywhere. ${ }^{65}$

The angels keep their ancient places

Turn but a stone and start a wing.

${ }^{63}$ Buber, I and Thou, pp. 58-9.

${ }^{64}$ Walter Kaufmann in Buber, I and Thou, p. 25. I am conscious that there are other possible interpretations of the tetragrammaton, for example that God is one 'who will be what He will': see Ernst Bloch, The Principle of Hope, trans. by N. Plaice, S. Plaice \& P. Knight (Oxford: Blackwell, 1986), pp. 1235-6.

${ }^{65}$ Plotinus, Ennead, VI.5 [23].7, 9f. The reference is to Homer's Iliad (I.197f), where Athena (the goddess of good sense) recalls Achilles from a murderous rage. 
'Tis ye, 'tis your estrangèd faces

That miss the many-splendoured thing. ${ }^{66}$

But I acknowledge also that we can indeed forget God's reality, can look away from it even though there is nowhere free of it. And this is perhaps, in our present state, a mercy. Consider some other words of Browning's Blougram: ${ }^{67}$

Pure faith indeed - you know not what you ask!

Naked belief in God the Omnipotent,

Omniscient, Omnipresent, sears too much

The sense of conscious creatures to be borne

It were the seeing him, no flesh shall dare.

Some think, Creation's meant to show him forth:

I say it's meant to hide him all it can,

And that's what all the blessed evil's for.

Its use in Time is to environ us,

Our breath, our drop of dew, with shield enough

Against that sight till we can bear its stress.

Under a vertical sun, the exposed brain

And lidless eye and disemprisoned heart

Less certainly would wither up at once

Than mind, confronted with the truth of him.

In the Plotinian story we have - partly - chosen to fall down into the world of seeming distance and difference, and so been alienated from our first home and Father. We are wrong to suppose that this world is the only truth, but would also be mistaken to make fond images of that 'other' world from which we may suppose we fell, as though we could reconstruct reality from our own impressions. Even the present delusion has its point, in offering us an almost bearable reminder of the reality we cannot easily face. To see Him, even to catch a glimpse of Him, we had better wait until we really are like Him: till then we see Him only in a pool, as it were, or polished silver! ${ }^{68}$

${ }^{66}$ Francis Thompson, 'The Kingdom of God', Selected Poems (London: Methuen, 1907), p. 133. See my essay 'Where have all the Angels gone?', Religious Studies, 28 (1992), 221-34.

${ }^{67}$ Browning, 'Bishop Blougram's Apology', lines 647-65.

${ }^{68}$ I Corinthians 13.12: the 'glass' here is a mirror not a windowpane, and - typically the ancients would have looked down into it: see further my Plotinus: Myth, Metaphor and Philosophical Practice, op.cit., pp. 85-86. 
Who it is that is God, and the very query, the unanswered and unanswerable question, gives us our first experience of the mystery. And though I earlier faintly disparaged the interpretation of 'wonder' as mere puzzlement, and its associated curiosity for some 'solution', this too is perhaps an element to be remembered. If everything possible happens, arising - in Plotinian terms - from mere matter, from mere possibility, the enterprise of explanation is both pointless and impossible. If enquiry is to have any point we must suppose that there are discoverable truths, that whatever happens is at least being guided, if not determined, by the forms of beauty. ${ }^{69}$ We are called to enquire into reality, without supposing that we ever have, or ever shall, achieve a full understanding of that same: we are to be, in a word, unhampered sceptics, zetetics or enquirers, stripped bare of opinions - as Philo said - so as to encounter God. ${ }^{70}$ 'Only those who, having disrobed themselves of all created things and of the innermost veil and wrapping of mere opinion, with mind unhampered and naked will come to God. ${ }^{71}$ In love, we seek always to get closer to the beloved, and that is at once an endless task and one accomplished in the very moment.

${ }^{69}$ See my 'A Plotinian Account of Intellect', American Catholic Philosophical Quarterly, 71 (1997), 421-32.

${ }^{70}$ See, for a slightly different take on the quest, my 'Living the Pyrrhonian Way', The Science, Politics, and Ontology of Life-Philosophy, Scott M. Campbell \& Paul W. Bruno (eds) (London: Bloomsbury, 2013), pp. 197-209.

${ }^{71}$ Philo, De Gigantibus, 12.53-4: Collected Works, trans. by F. H. Colson, G. H. Whitaker et al. (London: Loeb Classical Library, Heinemann, 1929), vol.2, pp. 470-3. 